\title{
HUBUNGAN PENDIDIKAN KEWIRAUSAHAAN DAN MINAT BERWIRAUSAHA TERHADAP SIKAP KEWIRAUSAHAAN MAHASISWA FAKULTAS EKONOMI UNIVERSITAS NEGERI MAKASSAR
}

\author{
Nilam Cahya Syahruddin ${ }^{1}$, Muhammad Azis ${ }^{2}$, Inanna ${ }^{3}$ \\ ${ }^{1}$ Pendidikan Ilmu Sosial Program Pascasarjana Universitas Negeri Makassar \\ Email: cahyanilam17@yahoo.com \\ ${ }^{2}$ Pendidikan Akuntansi Universitas Negeri Makassar \\ Email: azis_feunm@yahoo.com \\ ${ }^{3}$ Pendidikan Ekonomi Universitas Negeri Makassar \\ Email: inanna@unm.ac.id
}

\begin{abstract}
The purpose of this study was to find out the description of entrepreneurship education and entrepreneurial interest in Economic Faculty students of Makassar State University a partially and simultaneously. Data collection techniques are carried out through questionnaire techniques and documentation. Data analysis techniques are Normality Test, Linearity Test, Multiple Correlation Analysis, Bivariate, and F Test. The results showed that partially and simultaneously entrepreneurship education and entrepreneurial interest have a significant relationship to the entrepreneurial attitudes of students of the Economic Faculty of Makassar State University.
\end{abstract}

Keywords: Entrepreneurship education, entrepreneurship interest, entrepreneurship attitude.

\begin{abstract}
Abstrak.Tujuan penelitian ini adalah untuk mengetahui gambaran pendidikan kewirausahaan dan minat berwirausaha mahasiswa Fakultas Ekonomi Universitas Negeri Makassar secara parsial dan simultan. Teknik pengumpulan data dilakukan melalui teknik kuesioner dan dokumentasi.Teknik analisis data yang digunakan adalah Uji Normalitas, Uji Linearitas, Analisis Korelasi Berganda, Bivariate dan Uji F. Hasil penelitian menunjukkan bahwa secara parsial dan simultan pendidikan kewirausahaan dan minat berwirausaha memiliki hubungan yang signifikan terhadap sikap kewirausahaan mahasiswa Fakultas Ekonomi Universitas Negeri Makassar.
\end{abstract}

Kata Kunci: Pendidikan kewirausahaan, minat berwirausaha, sikap kewirausahaan

\section{PENDAHULUAN}

Selama ini, para lulusan sarjana dapat diibaratkan seperti "katak dalam tempurung". Artinya dalam benak mereka tertanam hanya satu pilihan setelah selesai kuliah, yakni mencari pekerjaan. Sedangkan kita ketahui bersama bahwa kondisi perkembangan ekonomi dunia dan adanya pasar bebas menuntut Indonesia untuk dapat menyejajarkan posisinya dengan dunia luar. (Hendro, 2011:14).

Hal ini dapat tercapai salah satunya dengan mengembangkan kewirausahaan di Negara Indonesia. Perkembangan mahasiswa agar memiliki pengetahuan intelektual maupun skill (kemampuan/ keterampilan) serta diharapkan bisa membawa perubahan bagi masyarakat terlebih lagi kewirausahaan tidak hanya dicapai dalam masyarakat yang bergerak di bidang itu, tetapi kewirausahaan juga merambah ke dunia pendidikan dasar maupun perguruan tinggi. Sekarang di Indonesia terdapat sistem ekonomi berbasis UKM dengan spirit of entrepreneurship yang kuat, konseptual dan tangguh. Selain program tersebut pemerintah melalui Direktorat Jenderal Pembelajaran dan Kemahasiswaan sekarang ini telah menawarkan Program Mahasiswa Wirausaha yang dikenal dengan sebutan PMW. "Peranan Perguruan tinggi adalah sebagai tempat untuk mendidik perubahan kepada Bangsa dan Negara. Sebagai pengemban tujuan pendidikan, maka Perguruan Tinggi menerima berbagai mahasiswa dari 
kalangan dan latar belakang keluarga yang berbeda-beda".

Zimmerer (2002:12), menyatakan bahwa salah satu faktor pendorong pertumbuhan kewirausahaan disuatu negara terletak pada peranan universitas melalui penyelenggaraan pendidikan kewirausahaan. Pihak universitas bertanggung jawab dalam mendidik dan memberikan kemampuan wirausaha kepada para lulusannya dan memberikan motivasi untuk berani memilih berwirausaha sebagai karir mereka. Pihak perguruan tinggi perlu menerapkan pola pembelajaran kewirausahaan yang kongkrit berdasar masukan empiris untuk membekali mahasiswa dengan pengetahuan yang bermakna agar dapat mendorong semangat mahasiswa untuk berwirausaha (Yohnson 2003, $\mathrm{Wu} \& \mathrm{Wu}, 2008)$.

Fenomena yang terjadi saat ini adalah peluang untuk mendapatkan posisi pekerjaan di instansi pemerintah yang semakin minim. Hal ini terlihat pada penerimaan calon pegawai negeri sipil setiap tahunnya, ini dikarenakan adanya Moratorium pemberhentian sementara penerimaan pegawai negeri sipil yang diputuskan pada tahun 2014 oleh Pemerintah dalam hal ini yaitu menteri Pendayagunaan Aparatur Negara dan Reformasi Birokrasi. Akibatnya banyak alumni perguruan tinggi yang telah menyandang status sarjana ini berbondongbondong untuk mendapatkan pekerjaan yang layak di instansi swasta. Akan tetapi dalam setiap fase penerimaan pegawai itu tidak mampu menampung keseluruhan para sarjana tersebut. akibatnya banyak yang kecewa karena tidak lulus dalam tes penerimaan pegawai tersebut. Realita tersebut menunjukkan perlunya pendidikan kewirausahaan untuk menanamkan kepribadian kreatif dan inovatif yang memiliki jiwa dan sikap kewirausahaan yang nantinya sumber daya manusia lulusan lembaga pendidikan tinggi cenderung lebih senang berusaha mandiri dengan membuka usaha baru dan menciptakan lapangan pekerjaan bagi dirinya dan orang lain.

Faktor lain yang berpengaruh adalah minat dalam berwirausaha. Minat merupakan faktor penting, karena segala sesuatu yang dilakukan lebih baiknya jika berasal dari keinginan diri sendiri. Sebagaimana yang diketahui bahwa menumbuhkan motivasi dalam diri seseorang termasuk motivasi berwirausaha adalah selain berasal dari faktor eksternal juga berasal dari faktor internal yang berasal dari dalam diri seseorang. Banyak orang sukses di dunia wirausaha karena menjadikan minat atau hobbinya sebagai suatu batu loncatan dalam menjalankan kegiatan kewirausahaannya.

Berdasarkan latar belakang yang dikemukakan di atas maka rumusan masalah dalam penelitian ini adalah bagaimanakah hubungan secara parsial dan simultan pendidikan kewirausahaan dan minat berwirausaha terhadap sikap kewirausahaan mahasiswa Fakultas Ekonomi Universitas Negeri Makassar?

\section{Pendidikan Kewirausahaan}

Pendidikan kewirausahaan adalah suatu proses pendidikan untuk mengetahui tentang segala sesuatu yang berhubungan dengan kewirausahaan mulai dari sikap/ perilaku sampai pada masalah untung \& rugi dalam berwirausaha. Lebih lanjut Soemanto (2002) menyatakan bahwa Pendidikan kewirausahaan adalah pertolongan untuk membelajarkan manusia Indonesia sehingga mereka memiliki kekuatan pribadi yang dinamis dan kreatif untuk menjalankan usahanya sesuai dengan kepribadian bangsa Indonesia yang berdasarkan Pancasila.

Program pengembangan jiwa

kewirausahaan telah dicanangkan oleh Presiden Republik Indonesia pada bulan Juli 1995. Setelah itu diluncurkan berbagai program rintisan pengembangan jiwa kewirausahaan di kalangan mahasiswa. Program Kreativitas Mahasiswa (PMW), KKN-Usaha dan Cooperative Education (Co-op) yang diluncurkan beberapa saat setelah pencanangan Presiden tersebut, telah banyak menghasilkan alumni yang terbukti lebih kompetitif di dunia kerja. Hasil-hasil karya inovasi mahasiswa melalui PMW potensial tersebut ditindaklanjuti secara komersial menjadi sebuah embrio bisnis berbasis Ilmu Pengetahuan, Teknologi dan Seni (Ipteks).

Dengan latar belakang program rintisan tersebut di atas, Direktorat Jenderal Pembelajaran dan Kemahasiswaan tahun 2009 ini mengembangkan sebuah Program Mahasiswa Wirausaha yang merupakan kelanjutan dari program-program sebelumnya, (PKM, Co-op, dan sejenisnya) untuk menjembatani para mahasiswa memasuki dunia bisnis rill melalui fasilitasi start-up bussines.

Prinsip dasar dalam pendidikan kewirausahaan adalah mereka harus dibuat tertarik dan termotivasi; kedua, mereka harus 
bisa dibuat melihat adanya kesempatan untuk bisnis yang menguntungkan (opportunity factors); ketiga, mereka harus memiliki beberapa keahlian seperti social skill, industrial skill, organizational skill dan strategic skill. Alma (2013: 6) bahwa, mata kuliah kewirausahaan diberikan dalam bentuk kuliah umum ataupun dalam bentuk konsentrasi program studi. Beberapa mata kuliah yang diberikan bertujuan antara lain:

a. Mengerti apa peranan perusahaan dalam sistem perekonomian.

b. Keuntungan dan kelemahan berbagai bentuk perusahaan.

c. Mengetahui karakteristik dan proses kewirausahaan.

d. Mengerti perencanaan produk dan proses pengembangan produk.

e. Mampu mengidentifikasi peluang bisnis dan menciptakan kreativitas serta membentuk organisasi kerjasama.

f. Mampu mengidentifikasi dan mencari sumber-sumber.

g. Mengerti dasar-dasar, marketing, financial, organisasi, dan produksi.

h. Mampu memimpin bisnis, menghadapi tantangan masa depan.

Perpaduan antara pendidikan dan pengalaman adalah faktor utama yang menentukan suatu keberhasilan wirausaha. Menurut Husain (2007:47) Selain bekal kemampuan, wirausaha juga perlu memiliki pengetahuan dan keterampilan. Bekal pengetahuan yang harus dimiliki oleh wirausaha, meliputi:

1. Bekal pengetahuan mengenai usaha yang akan dirintis dan lingkungan usaha.

2. Bekal pengetahuan tentang peran dan tanggungjawab.

3. Bekal pengetahuan tentang organisasi dan manajemen bisnis.

\section{Minat Berwirausaha}

Minat sangat berperan penting terhadap sikap seseorang dalam kegiatan kewirausahaan karena dengan minat maka seseorang dapat melakukan sesuatu yang dicita-citakannya sesuai dengan dorongan yang berasal dari dirinya sendiri.

Minat memiliki sejumlah karakteristik atau ciri-ciri tertentu. Adapun ciri-ciri dari minat menurut Achmadi (1998:64) adalah sebagai berikut:
(1) minat tidak dibawa sejak lahir, melainkan dibentuk dan dipelajari sepanjang perkembangan orang itu dalam hubungannya dengan objeknya; (2) minat dapat berubah-ubah, sejalan dengan kedekatan hubungan orang itu dengan objeknya; (3) minat itu tidak berdiri sendiri, melainkan mempunyai hubungan dengan suatu objek; (4) objek minat bukan satu hal saja, tetapi dapat merupakan kumpulan hal-hal tertentu; dan (5) minat mempunyai segi motivasi dan perasaan (feeling).

Minat berwirausaha menyebabkan seorang cenderung melakukan aktivitas yang berhubungan dengan usaha yang mereka ingin sukses di dalamnya dengan menggunakan sumber daya dan dorongan dari dalam diri mereka. Dari rasa tertariknya maka mereka akan berusaha mempelajari bidang atau sesuatu yang terkait dengan dunia kewirausahaan atau lebih dikenal dengan istilah entrepereneurship.

\section{Sikap Kewirausahaan}

Arifin (2012) mengatakan bahwa, "Sikap kewirausahaan merupakan suatu kencenderungan dan ketersedian untuk bereaksi atau bertindak seseorang (mahasiswa) terhadap nilai-nilai atau aspek-aspek yang terkandung pada diri seorang wirausaha”. Sikap kewirausahaan karyawan adalah kecenderungan berpikir (kognitif), merasa (afektif), dan berperilaku (konatif) dari karyawan dalam bekerja yang mengarah pada upaya mencari, menciptakan, menerapkan cara kerja, teknologi, dan produk baru dengan meningkatkan efisiensi, memberikan pelayanan yang lebih baik dan atau memperoleh keuntungan yang lebih besar (Winarno, 2011: 22).

Pembentukan sikap tidak terjadi dengan sendirinya dan sikap tidak dibawa sejak lahir. Tetapi pembentukan sikap berlangsung dalam interaksi manusia, dan berkenaan dengan objek tertentu. Interaksi sosial di dalam kelompok maupun di luar kelompok dapat mengubah sikap (Gerungan, 1996:154). Sikap lebih banyak diperoleh dari belajar daripada sifat bawaan. Sikap dapat ditumbuhkan, dikembangkan ke arah yang positif, dipelihara dan bahkan diperlemah melalui proses belajar.

Menurut Garret (dalam Abror, 1993:110), ada dua faktor yang mempengaruhi pembentukan dan perubahan sikap, yaitu:

a. Faktor Psikologis, seperti motivasi, emosi, pemilikan, kekuasaan, kebutuhan, dan kepatuhan. 
b. Faktor kultural atau kebudayaan seperti status sosial, lingkungan keluarga, dan pendidikan.

Faktor psikologis dalam penelitian ini adalah meliputi motivasi yang dikhususkan pada motivasi internal yakni minat berwirausaha, sedangkan faktor kultural dalam penelitian ini adalah pendidikan kewirausahaan.

Menurut Geoffrey G. Meredith (dalam Husain 2007:17) mengemukakan ciri-ciri dan watak kewirausahaan seperti berikut:

a. Percaya diri dan optimis, yakni Memiliki kepercayaan diri yang kuat, ketidaktergantungan terhadap orang lain, dan individualistis.

b. Berorientasi pada tugas dan hasil yaitu Kebutuhan untuk berprestasi, berorientasi laba, mempunyai dorongan kuat, energik, tekun dan tabah, tekad kerja keras, serta inisiatif.

c. Berani mengambil resiko dan mempunyai tantangan, yakni Mampu mengambil resiko yang wajar.

d. Kepemimpinan, yakni Berjiwa kepemimpinan, mudah beradaptasi dengan orang lain, dan terbuka terhadap saran serta kritik.

e. Keorsinilan, yakni memiliki jiwa Inovatif, kreatif dan fleksibel.

f. Berorientasi masa depan, dimana Memiliki visi dan perspektif terhadap masa depan.

\section{METODE PENELITIAN}

Metode yang digunakan adalah menggunakan angket dengan lima alternatif jawaban. Dalam angket tersebut peneliti memberikan angka atau bobot untuk item-item pertanyaan/ pernyataan dengan menggunakan Skala Likert, di mana responden akan diminta untuk menyatakan kesetujuan atau ketidak setujuannya terhadap isi pertanyaan/ pernyataan.

Uji coba instrumen yang dilakukan adalah analisis keabsahan data yang terdiri atas uji validitas dan uji reliabilitas. Sedangkan untuk teknik analisis data menggunakan uji normalitas dan linearitas, analisis statistik data yang terdiri atas korelasi berganda dan pengujian hipotesis menggunakan bivariate dan Uji-F.

\section{HASIL DAN PEMBAHASAN}

Berdasarkan hasil uji validasi menunjukkan semua item pertanyaan dari setiap variabel yang dikaji dalam penelitian ini adalah valid ditunjukkan melalui nilai sig. (2-tiled) kurang dari 0,05. Selain itu nilai Pearson Correlation untuk semua item pertanyaan pada masing-masing variabel memiliki tanda bintang. Sedangkan dari pengujian realibilitas instrumen penelitian, menunjukkan cronbach's alpha $>0,50$ maka dapat disimpulkan bahwa instrumen yang digunakan dalam penelitian ini memiliki tingkat konsistensi jawaban responden yang layak atau reliabel. Untuk uji normalitas menunjukkan nilai asymp. Sig. (2-tailed sebesar 0,200 yang artinya variabel yang diujikan normal, dan untuk uji linearitas variabel pendidikan kewirausahaan terhadap sikap kewirausahaan untuk kategori Deviation from Linearity pada tabel Anova sebesar 0,358 yang berarti lebih besar dari Alpha 0,05 . Dengan demikian dapat disimpulkan bahwa terdapat hubungan yang linear signifikan antara variabel pendidikan kewirausahaan terhadap sikap kewirausahaan.

Sedangkan minat berwirausaha terhadap sikap kewirausahaan untuk kategori Deviation from Linearity pada tabel Anova sebesar 0,15 yang berarti lebih besar dari Alpha 0,05. Dengan demikian dapat disimpulkan bahwa terdapat hubungan yang linear signifikan antara variabel minat berwirausaha terhadap sikap kewirausahaan.

\section{Uji Parsial (Bivariate)}

Untuk menguji hubungan variabel bebas apakah masing-masing variabel independen mempunyai hubungan terhadap variabel dependen.

Tabel 1. Hasil Korelasi Product Moment Pendidikan Kewirausahaan terhadap Sikap Kewirausahaan

Correlations

\begin{tabular}{|c|c|c|c|}
\hline & & $\begin{array}{c}\text { Pendidikan } \\
\text { kewirausahaan }\end{array}$ & Sikap kewirausahaan \\
\hline \multirow{3}{*}{$\begin{array}{l}\text { Pendidikan } \\
\text { kewirausahaan }\end{array}$} & Pearson Correlation & 1 & $.472^{* *}$ \\
\hline & Sig. (2-tailed) & & .000 \\
\hline & $\mathrm{N}$ & 135 & 135 \\
\hline \multirow{3}{*}{$\begin{array}{l}\text { Sikap } \\
\text { kewirausahaan }\end{array}$} & Pearson Correlation & $.472^{* *}$ & 1 \\
\hline & Sig. (2-tailed) & .000 & \\
\hline & $\mathrm{N}$ & 135 & 135 \\
\hline
\end{tabular}


Sumber: Hasil Olah Data SPSS 2018

Berdasarkan hasil analisis data menggunakan Product Moment di atas menunjukkan bahwa nilai signifikansi hubungan pendidikan kewirausahaan dan sikap kewirausahaan sebesar 0,000. Artinya karena nilai ini lebih kecil dari 0,05 maka dapat dikatakan bahwa terdapat hubungan yang signifikan antara pendidikan kewirausahaan terhadap sikap kewirausahaan. Kemudian pada derajat hubungan, pada nilai person correlation sebesar 0,472 kalau dilihat pada rujukan yang berada pada lampiran berarti tingkat hubungan antara pendidikan kewirausahaan terhadap sikap kewirausahaan berada pada kategori sedang. Atau apabila didistribusikan pada $\mathrm{r}$ tabel maka diperoleh $r$ tabel sebesar 0,159 jadi $0,475>$ dari 0,159 yang berarti terdapat hubunganyang signifikan antara variabel pendidikan kewirausahaan terhadap sikap kewirausahaan.

Tabel 2. Hasil Korelasi Product Moment Minat Berwirausaha terhadap Sikap Kewirausahaan

Correlations

\begin{tabular}{llcc}
\hline & & Minat berwirausaha & Sikap kewirausahaan \\
\hline Minat Berwirausaha & Pearson Correlation & 1 & $.751^{* *}$ \\
& Sig. (2-tailed) & & .000 \\
& $\mathrm{~N}$ & 135 & 135 \\
Sikap & Pearson Correlation & $.751^{* *}$ & 1 \\
Kewirausahaan & Sig. (2-tailed) & .000 & 135 \\
& $\mathrm{~N}$ & 135 & 135 \\
\hline
\end{tabular}

Sumber: Hasil Olah Data SPSS 2018

Berdasarkan hasil analisis data menggunakan Product Moment di atas menunjukkan bahwa nilai signifikansi hubungan pendidikan kewirausahaan dan sikap kewirausahaan sebesar 0,000. Artinya karena nilai ini lebih kecil dari 0,05 maka dapat dikatakan bahwa terdapat hubungan yang signifikan antara minat berwirausaha terhadap sikap kewirausahaan. Kemudian pada derajat hubungan, pada nilai person correlation sebesar 0,751 kalau dilihat pada rujukan yang berada pada lampiran berarti tingkat hubungan antara minat berwirausaha minat berwirausaha terhadap sikap kewirausahaan berada pada kategori kuat. Atau apabila didistribusikan pada $r$ tabel maka diperoleh $r$ tabel sebesar 0,159 jadi $0,751>$ dari 0,159 yang berarti terdapat hubungan antara variabel pendidikan kewirausahaan terhadap sikap kewirausahaan.

\section{Uji F (Uji Simultan)}

Untuk menguji pengaruh variabel bebas secara bersama- sama diuji dengan menggunakan uji $\mathrm{F}$ dengan menggunakan SPSS 20.0 .

Berdasarkan hasil analisis data maka diperoleh persamaan yaitu:

$$
\mathrm{Y} /=0,752+0,565 \mathrm{X} 1+0,558 \mathrm{X} 2
$$

Nilai signifikansi hubungan pendidikan kewirausahaan dan minat berwirausaha terhadap

sikap kewirausahaan sebesar 0,000. Artinya jika nilai signifikansi atau $\mathrm{F}$ change lebih kecil dari 0,05 maka artinya ada korelasi.

Kemudian untuk melihat tingkat keeratan hubungan tersebut yaitu dengan melihat nilai $\mathrm{R}$ atau nilai koefisien korelasi dari sini diperoleh nilai sebesar 0,752 kemudian dikonsultasiakan pada pedoman derajat hubungan yaitu terletak pada $0,61-0,80$ artinya derajat hubungan antara variabel pendidikan kewirausahaan dan minat berwirausaha terhadap sikap kewirausahaan adalah merupakan kategori korelasi kuat.

Pada tabel uji $\mathrm{F}$ pendidikan kewirausahaan dan minat berwirausaha terhadap sikap kewirausahaan juga diperoleh nilai $R$ Square atau koefisien determinasi yang menunjukkan seberapa bagus model regresi yang dibentuk oleh interaksi variabel bebas dan terikat. Nilai koefisien determinasi yang diperoleh adalah 0,565 atau sebesar 56,5\%, yang dapat ditafsirkan bahwa dari sikap kewirausahaan pada mahasiswa Fakultas Ekonomi UNM, dapat dijelaskan atau dipengaruhi oleh pendidikan kewirausahaan dan minat berwirausaha, selebihnya yaitu $43,5 \%$ dipengaruhi oleh faktor lain yang tidak dimasukkan dalam variabel penelitian. 
Nilai Adjusted R Square sebesar 55,8,\% mengandung makna bahwa apabila variabel bebas yang digunakan untuk mengukur tingkat sikap kewirausahaan pada mahasiswa Fakultas Ekonomi UNM ditambah variabel lain selain pendidikan kewirausahaan dan minat berwirausaha.ng maksimal perlu didukung dengan kompetensi-kompetensi yang harus dimiliki oleh seorang guru untuk menjalankan keprofesiannya". Sejalan dengan pendapat Kasmir (2016:189) yang menyatakan bahwa "kemampuan dan keahlian akan mempengaruhi kinerja seseorang".

Tabel 3. Uji F Pendidikan Kewirausahaan dan Minat Berwirausaha terhadap Sikap Kewirausahaan

Model Summary

\begin{tabular}{rrrrrrrrrrrr}
\hline & & \multicolumn{3}{c}{} & \multicolumn{3}{c}{ Std. Error of } & \multicolumn{4}{c}{ Change Statistics } \\
Model & $\mathbf{R}$ & $\begin{array}{c}\text { R } \\
\text { Square }\end{array}$ & $\begin{array}{c}\text { Adjusted R } \\
\text { Square }\end{array}$ & $\begin{array}{c}\text { the } \\
\text { Estimate }\end{array}$ & & $\begin{array}{c}\text { R Square } \\
\text { Change }\end{array}$ & $\begin{array}{c}\text { F } \\
\text { Change }\end{array}$ & df1 & df2 & Sig. F Change \\
\hline 1 & $.752^{\mathrm{a}}$ & .565 & .558 & 6.099 & & .565 & 85.651 & 2 & 132 & .000 \\
\hline
\end{tabular}

Sumber: Hasil Olah Data SPSS 2018

\section{PEMBAHASAN}

\section{Gambaran Pendidikan Kewirausahaan Pada Mahasiswa Fakultas Ekonomi Universitas Negeri Makassar}

Hasil analisis data menggunakan Product Moment menunjukkan bahwa nilai signifikansi hubungan pendidikan kewirausahaan dan sikap kewirausahaan sebesar 0,000. Artinya terdapat hubungan yang signifikan antara pendidikan kewirausahaan terhadap sikap kewirausahaan. Hal ini dapat dilihat dari indikator pengetahuan mengenai peran, pengetahuan mengenai tanggungjawab, pengetahuan mengenai usaha dan lingkungan usaha, pengetahuan organisasi dan manajemen bisnis.

Pendidikan kewirausahaan pada dasarnya $\mathbf{1}$. akan memberi dorongan terhadap sikap kewirausahaan mahasiswa atau ketersediaan untuk bereaksi atau bertindak seorang mahasiswa terhadap aspek yang terkandung pada diri wirausaha, sejalan dengan hal tersebut Wijaya (2012) mengemukakan bahwa pendidikan kewirausahaan tidak hanya memberikan landasan teoritis mengenai konsep kewirausahaan tetapi membentuk sikap, perilaku, dan pola pikir seorang wirausaha.

Gambaran Minat Berwirausaha Pada Mahasiswa Fakultas Ekonomi Universitas Negeri Makassar

Hasil analisis data menggunakan Product Moment menunjukkan bahwa nilai signifikansi hubungan pendidikan kewirausahaan dan sikap kewirausahaan sebesar 0,000 . Artinya terdapat hubungan yang signifikan antara minat berwirausaha terhadap sikap kewirausahaan, hal ini dapat dilihat dari indikator memiliki perhatian lebih terhadap objek tertentu, memiliki keinginan besar terhadap sesuatu, melakukan sesuatu secara berkelanjutan, dan memiliki motivasi yang besar untuk melakukan sesuatu. Terkait dengan kinerja guru, apabila seorang guru memiliki dorongan yang kuat dari dalam atau luar dirinya, maka guru akan terangsang untuk melakukan pekerjaannya dengan sebaik mungkin yang kemudian berpengaruh terhadap kinerjanya, seperti yang dikemukakan oleh Kasmir (2016:191) bahwa "motivasi memengaruhi kinerja seseorang".

Hubungan Pendidikan Kewirausahaan Dan Minat Berwirausaha Secara Parsial dan Simultan Terhadap Sikap Kewirausahaan Mahasiswa Fakultas Ekonomi Universitas Negeri Makassar.

Penelitian ini menunjukan adanya hubungan yang signifikan dari pendidikan kewirausahaan dan minat berwirausaha dalam menumbuhkan sikap kewirausahaan mahasiswa Fakultas Ekonomi Universitas Negeri Makassar. Penelitian ini juga menunjukkan adanya hubungan yang kuat antara variabel bebas dan variabel terikat.

Pendidikan kewirausahaan dan minat berwirausaha apabila dikolaborasikan maka akan memunculkan sikap dalam berwirausaha karena sejatinya pendidikan kewirausahaan dapat membangun kemampuan, pengetahuan, dan pembentukan karakter yang penting bagi 
kreativitas. Dan juga pendidikan kewirausahaan dapat memunculkan minat berwirausaha pada diri seorang mahasiswa dan selanjutnya mahasiswa akan melakukan tindakan atau melakukan aktivitas kewriusahaan sehingga nantinya akan mendorong minat atau keinginan.

Hasil penelitian Gallant et al (2010) mengatakan bahwa kewirausahaan dipandang sebagai sumber penting bagi pertumbuhan ekonomi dan pendidikan kewirausahaan merupakan komponen penting dalam penciptaan dan pengembangan sikap kewirausahaan. Garret juga mengemukakan hal yang sama yaitu ada dua faktor yang dapat mempengaruhi pembentukan dan perubahan sikap yaitu faktor psikologi yang melipti motivasi atau minat dan faktor kultur yang meliputi pendidikan

\section{SIMPULAN DAN SARAN Simpulan}

Berdasarkan dari hipotesis penelitian, hasil olah data dan pembahasan, maka kita dapat menarik kesimpulan bahwa Pendidikan Kewirausahaan dan Minat Berwirausaha memiliki korelasi atau hubungan yang signifikan terhadap Sikap Kewirausahaan Mahasiswa Fakultas Ekonomi Universitas Negeri Makassar.

\section{Saran}

Berdasarkan dari hasil penelitian yang telah dilakukan maka peneliti memberikan saran kepada pihak-pihak yang terkait sebagai berikut:

1. Kepada guru terutama guru ekonomi pada SMA Negeri di Kota Makassar yang telah Untuk lebih meningkatkan kualitas pendidikan kewirausahaan sehingga dapat memberikan semangat pada mahasiswa untuk berwirausaha.

2. Selain teori dosen juga diharapkan mampu memberikan praktek secara langsung mengenai kewirausahaan.

3. Menambah jumlah SKS mengenai mata kuliah pendidikan kewirausahaan agar mahasiswa bisa lebih memperdalam pengetahuan mengenai dunia wirausaha.

\section{DAFTAR PUSTAKA}

Alma, Buchari. 2013. Kewirausahaan untuk Mahasiswa dan Umum. Bandung: Alfabeta.

Arikunto, Suharsimi. 2013. Prosedur Penelitian Suatu Pendekatan Praktik. Jakarta: PT Rineka Cipta.
Drucker, Peter F. 1996. Inovasi dan Kewiraswastaan Praktek dan DasarDasar. Jakarta: Penerbit Erlangga..

Azwar, Budi. 2013. Analisis Faktor-faktor yang Mempengaruhi Niat Kewirausahaan (Entrepreneurial Intention) (Studi Terhadap Mahasiswa Universitas Islam Negeri SUSKA Riau). MENARA. 12 (1): 12-22.Priansa, Donni.J. 2014. Kinerja dan Profesionalisme Guru. Bandung: Alfabeta.

Gerba, D Tessema,. 2012. Impact of Entrepreneurship Education on Entrepreneurial Intentions of Business and Engineering Students in Ethiopia. African Journal of Economic and Management Studies. 3 (2): 258-277.

Gerungan, W. A. 2000. Psikologi Sosial. Bandung: Refika Aditama.

Gibson, S. G., Harris, M. L., Mick, T. D., \& Burkhalter, T. M. 2009. Comparing the Entrepreneurial Attitudes of University and Community College Students. United States Association for Small Business and Entrepreneurship, Conference Proceedings. p: 1059.

Hendro. 2011. Dasar-Dasar Kewirausahaan. Jakarta: Penerbit Erlangga.

Soemanto, Wasty. 2002. Sekuncup Ide Operasional Pendidikan Wiraswasta. Jakarta: Bumi Aksara.

Syam, Husain. 2007. Kewirausahaan: Langkah Praktis Menuju Sukses. Makassar: Badan Penerbit Universitas Negeri Makassar.

Zimmerer, W.T. 2002. Essentials of Entrepreneurship and Small Business Management. Third Edition. New York: Prentice-Hall. 